\title{
Pragmatic competence of teachers: a contrastive case study of native and non-native teachers of English
}

\author{
Anna SZCZEPANIAK-KOZAK \\ Adam Mickiewicz University in Poznań \\ E-mail: szczepaniakkozak@gmail.com \\ Emilia WĄSIKIEWICZ-FIRLEJ \\ Adam Mickiewicz University in Poznań \\ E-mail: emiliawf@amu.edu.pl
}

\begin{abstract}
The existing studies on pragmatic competence of English teachers, e.g., J. Majer and $Ł$. Salski (2004), E. Krawczyk-Neifar (2004), M. Savič (2016), A. Szczepaniak-Kozak and E. Wąsikiewicz-Firlej (in press), indicate that it is not varied and requires improvement in certain areas. These deficiencies might be interpreted as a result of not only the absence of pragmatic competence (PC) modules in teachertraining education but also a relatively low frequency of English teachers' contact with native speakers (NS) of English (A. Szczepaniak-Kozak 2010). Nevertheless, we know very little what shape teacher PC takes, including the way it differs from that represented by NSs. Additionally, to the best of our knowledge, there are no studies based on data collected in naturalistic settings (lessons of English). Consequently, this paper attempts to fill in this gap in research by presenting the methodology and conduct of a case study, based on classroom observation of teachers' pragmatic performance, to investigate whether there are differences in the PC represented by non-native teachers (NNTs) and native teachers (NTs) of English. The findings indicate that NTs do not hold the upper hand in this regard and that a demonstrable linguistic and pragmatic competence, along with appropriate professional training, are better indicators of diverse pragmatic input. On this basis, we propose that some degree of proficiency in pragmatics and its teaching should be a requirement for a certificate or diploma for future foreign language teachers.
\end{abstract}

Keywords: pragmatic competence, teacher pragmatic, competence, requests, classroom discourse, teaching of target language pragmatics

\section{Introduction: terms explained}

Pragmatic competence (PC) entails "knowing the extent to which an utterance is acceptable and appropriate to other users of the language in conveying the speaker's intended meaning" or purpose (L. Wyner/ A. Cohen 2016: 521) and being able to apply linguistic resources to express this knowledge and, very often, to achieve a specific goal (M. Gomez-Laich 2016: 250). The shape and tempo of acquiring PC in our mother tongue (MT) and in any foreign language (FL) we are learning differ significantly, primarily because the latter process is under a considerable influence of the sociopragmatic competence that we acquire in the former. Furthermore, to be pragmatically competent, learners of the target language (TL) need to acquire the knowledge base and the ability of the contextual adjustment of linguistic resources 
jointly with the ability to efficiently monitor and control each of them in spontaneous communication (N. Taguchi 2011). Notably, researchers busying themselves with teaching and learning of PC convincingly argue that 1) the FL classroom does not foster a sustained and balanced development of $\mathrm{PC}$, and 2) the explicit teacher intervention has a more noticeable and lasting facilitative effect than the indirect one, especially when the former comprises direct (meta)pragmatic information on TL pragmatic features. In other words, instructed learners outpace their uninstructed peers (cf. K. Bardovi-Harlig 2001, J. Félix-Brasdefer 2008a, b, G. Kasper 2001a, G. Kasper/ K. Rose 2002, A. Cohen 2016). Implicit instruction can benefit learners as well but it should involve noticing and processing activities (N. Taguchi 2015) in the presence of an informed teacher. Regardless of which instruction modality is chosen, only teachers can "heighten student awareness as to similarities and differences in both sociopragmatic and pragmalinguistic behavior across cultural groups" and indicate which resources can be used to convey such an understanding (A. Cohen 2016: 564). Instruction gains particular importance in groups of adult learners because it increases the probability that they notice pragmatic features in the input provided.

The above research-driven conclusions constitute especially good news for learners in FL contexts. They have considerable chances of becoming pragmatically competent if the application of a given grammatical or lexical element to render a pragmatic content is brought to their conscious attention, and if so-oriented teaching/learning repeatedly takes place. The intake can be further enhanced if learners are exposed to well-articulated feedback. However, P. Seedhouse's (2001: 368-369) comprehensive report on the strategies that teachers employ to repair errors committed by learners, based on transcripts of 330 lessons from 11 countries, indicates that teachers disprefer explicit and overt negative feedback in order not to embarrass or dismotivate students (ibidem: 367 ). It is our conviction that teachers also avoid situations when other students in the class relay feedback to their peers. Such teacher behavior limits the repertoire of suggestions students learn in the classroom and, equally importantly, does not stimulate their (pragmatic) awareness.

Turning now to the language which is the focus of the present case study English, the reality is that even advanced learners of English as a foreign language (EFL) do not have a full range of lexis and grammar to achieve their goals effortlessly and fluently in this language with simultaneous adherence to the rules of pragmatic appropriateness (cf. K. Akikawa 2010, A. Szczepaniak-Kozak 2016, in press). Additionally, they do not have frequent opportunities and/or enough eagerness to engage in conversations in the TL in natural contexts. This situation implies that they seldom have a true communicative need (J. Cenoz 2008: 132) and ever rarer get feedback from other users of the TL. In such circumstances, EFL learners need an aware and skilful teacher who could model and demonstrate how to perform tasks in a pragmatically appropriate way (L. Wyner/ A. Cohen 2016: 524) and involve them in tasks that could foster the development of their flexibility in adjusting linguistic resources to contextual nuances. Bringing this matter to teachers' attention is a particularly pressing task in Poland. 
There are very few studies of EFL teachers' PC. Those which are available, in the predominant number of cases, pertain to the effects of the implemented changes to the curriculum on the shape of their pragmatic awareness and PC in general, e.g., Z. Eslami-Rasekh (2005), Z. Eslami/ A. Eslami-Rasekh (2008), L. Yates / G. Wiggglesworth (2005), C. Vásquez / A. Fioramonte (2011), N. Ishihara (2011), K. Akikawa (2010), and M. Savič (2016). There are even fewer rigorous studies concerning PC of teachers of English, based on naturalistic data collected during ongoing lessons. In this sense, our paper constitutes an attempt to fill in this evident gap in research.

In what follows, we concentrate only on one aspect which enables learners to develop their PC in FL settings, i.e., teacher talk (pedagogical discourse) based on the widely accepted assumption that: "the learners learn from the teacher how to manipulate linguistic forms accurately" (P. Seedhouse 2001: 353). In doing so, we argue that one of the reasons why non-native speakers of English do not achieve the target language $\mathrm{PC}$ is the quality and character of the input that they receive from their teachers in formal instruction settings. In order to realize this goal, and putting aside the issue of which variety of the TL (British, American, lingua franca, etc.) is to be taught, we report our case-study findings with regard to the handling of pragmatics by native and non-native teachers in the FL classroom. We also intend to list possible advantages or disadvantages of native and non-native teachers when it comes to the development of PC in formal instruction settings.

\section{Pragmatic competence of teachers of English}

Since in the predominant number of cases teachers constitute one of the very few, if not the only, source of the TL input in the Expanding Circle (B. Kachru 1985: 12), this input is very often the model which language learners imitate. In this sense, the teacher's competence serves as a model for his or her learners' linguistic, including pragmatic, output and, in a more general manner, shapes their (pragmatic) competence. At the same time, however, there are several research reports confirming that teacher talk ${ }^{1}$ is not an ideal input, as it does not necessarily raise learners' pragmatic knowledge and ability in the classroom (K. Bardovi-Harling/ B. Hartford 1993; J. Majer/ Ł. Salski 2004, A. Szczepaniak-Kozak/ E. Wąsikiewicz-Firlej, in press). This is so because the input provided by the teacher features characteristic pragmalinguistic forms - the forms used to render politeness or appropriateness are typical of the socio-cultural context of the school: a considerable power distance between the teacher and the student, a small degree of the imposition present in classroom tasks and activities, a fossilized arrangement of the teacher's rights and students' obligations. Consequently, this input may typically be far away from the appropriate, contextualized forms, which are frequently used by native speakers of

1 Teacher talk involves "simplified register, syntactic simplification, reduced length of utterances, and no ungrammatical speech” (A. Martínez-Flor/ E. Usó-Juan 2010: 10). 
English ${ }^{2}$. This is primarily because "classroom discourse is regarded as an institutional variety of discourse, in which interactional elements correspond neatly to institutional goals" (P. Seedhouse 1996: 16). Therefore, by its very nature, it is different from everyday conversations. P. Seedhouse (1996:18) argues that conversation is "a speech event outside of an institutionalized setting involving at least two participants who share responsibility for the progress and outcome of an impromptu and unmarked verbal encounter consisting of more than a ritualized exchange" [italics added]. For instance, due to the unequal distribution of power in the classroom, specific pragmatic patterns occur in it, which is neatly evidenced by existing studies of the classroom discourse, e.g., J. Majer and Ł. Salski (2004), M. Savič (2016), A. Szczepaniak-Kozak and E. Wąsikiewicz-Firlej (in press).

Another inherent risk in resting NNTs with the sole responsibility for designing pragmatically fruitful instruction is that they may not be sufficiently socialized in the TL, here English, and thus not necessarily highly competent in the TL. This may be substantiated by the findings of the study conducted by the first author of this paper by means of self-perception anonymous questionnaires, which were designed to elicit answers to the question of how Intercultural Communicative Competence (ICC) is taught in Poland (A. Szczepaniak-Kozak 2010). The study revealed, among other things, that EFL teachers in Poland seldom visit English speaking countries or have contacts with NSs so they do not feel experts in cultural aspects (ibidem: 124). The lack of such experience definitely hinders the development of their PC and, consequently, their effective performance in the classroom because both ICC and PC are fostered by sustained contextualized interactions in the TL and heightened awareness leading to understanding. Teachers showing deficit in their own PC in a foreign language are not able to foster the development of this competence in others, primarily because they have not developed "critical awareness of pragmatic variability $[. .$.$] and thus lack the tools of cross-cultural analysis and negotiation needed$ to help their students be open and observant enough to note and accept pragmatic norms different from their own" (K. Akikawa 2010: 54).

To support their learners' pragmatic socialization, teachers need to show comfortable expertise in EFL pragmatic practices, have a considerable metapragmatic awareness (G. Kasper/ K. Rose 2002a: 52) and realize the importance of teaching pragmatics. However, this may not go unimpeded in Poland, where more often than not EFL teachers "do not have the feel for the TL and they themselves may have never been taught pragmatic aspects of grammar" (M. Pawlak 2006: 49-50). Since they may never have studied pragmatics in their teaching preparation courses, they "inadvertently pass on this lack of knowledge to students" (L. Wyner / A. Cohen 2016: 542), who will remain oblivious to the manner in which contextual nuances should influence communication. A. Cohen's (2016) research conducted among language teachers worldwide provides illustrative evidence for this stance. In his questionnaire

\footnotetext{
${ }^{2} \mathrm{We}$ are fully aware of the ongoing debate about what the Standard English is and the growing recognition of English as a lingua franca as a variety of English in its own right. However, for our discussion of PC, we are more concerned about being appropriate and polite in English rather than correct. Hence, such divisions are of lesser significance in this paper.
} 
study distributed among 30 native and 83 non-native teachers of different languages (113 teachers in total), it appeared that "the teachers were relatively similar in what they reported" with regard to the extensiveness of their coverage of selected pragmatic features, for instance, politeness, requests, thanks, curses, sarcasm, criticism, in their teaching. Native teachers (NT) gain the upper hand in this respect concomitantly with an increase in their teaching experience. No correlation between the declared years of teaching and the amount of pragmatic content present in formal classroom teaching was found for non-native teachers (NNT) (A. Cohen 2016: 569-570). A. Cohen (2016: 583) explains this finding on the grounds of teachers' "relative lack of awareness of pragmatics or their intent to simply follow textbook lessons over the years". His study also lends support to K. Akikawa's (2010: 48) ruminations concerning the low level of comfort, which NNT experience when teaching pragmatics, predominantly because they do not feel experts in the TL pragmatics (after A. Cohen 2016: 571-572). All in all, on the basis of the data collected, A. Cohen (2016: 581) concludes that 'NTs' intuitions about pragmatics may assist them in teaching learners how to be effectively critical and sarcastic, as well as how to respond appropriately to criticism and sarcasm. The caveat here is that relying on NS [native speaker] intuition may be misleading".

Notably, research conducted among student-teachers and teachers of EFL in Poland leaves little ground for optimism about their PC in English. First of all, none of the participants in K. Droździał-Szelest's (2011) study on aspects of instructed speaking and communicative strategies enumerates low PC as a source of their communicative failures. Apart from their low pragmatic awareness, they also find language correctness more important than appropriateness (ibidem: 141-143), which is a typical trait in future teachers of EFL (cf. K. Niezgoda / C. Röver 2001, G. Schauer 2009). In a similar vein, student-teachers in E. Krawczyk-Neifar's (2004: 42-46) research were not able to define the term pragmatics or pragmatic competence. The techniques of PC development that they listed are vague and intuitive rather than grounded in the methodology of teaching foreign languages.

With reference to speech acts rendered by teacher-trainees, A. Klimczak's (2011) study into their strategy preference when performing apologies is noteworthy because it was conducted with the participation of 89 Polish, 74 Macedonian, 56 Slovak, 20 Dutch, and 7 English students who were planning to become English teachers. Her research findings indicate that future teachers representing different national groups perform differently in the same situations requiring apologies, which "can further suggest that the type of responses they teach their students and the politeness model they will present will differ" (A. Klimczak 2011: 96). These findings enabled her to conclude that "English teachers across Europe do not share the same pragmatic competence and that therefore there is a need for introducing a new approach to teaching speech acts" (ibidem: 93-94). Relatedly, our own observations conducted in teacher-trainee classes led us to the conclusion that teachers seem to develop their own discursive patterns and shape their classroom discourse accordingly (A. Szczepaniak-Kozak/ E. Wąsikiewicz-Firlej, in press). With time, it seems as if all their classes followed a similar pattern or script. For instance, teachers' repertoire of 
requestive strategies is limited and relies on directive strategies to a great extent. This implies that certain interactional exchanges constantly reappear in their classes and some others never do, which naturally has a colossal influence on what type of pragmatic features appear in their micro-worlds.

Turning now to the pragmatic feature which serves the operationalization of PC in the present study, that is, requests and their mitigation in formal classroom discourse, they are produced mostly by teachers when involved in the realization of framework goals. Thus, they are produced as part of organizational language (cf. R. Ellis 1992). For example, R. Ellis (1992: 17-18), in the paper analyzing the development of requestive behavior in two ESL learners in formal language classes, notices that when requests appeared in the classroom they were mainly a result of "the communicative needs that arose in the course of setting up and staying on tasks of various kinds" and not the outcome of planned instruction (ibidem). Additionally, because classroom discourse often relies on routinized formulas, the input provided to students is impoverished and shows almost no variation. Consequently, the repertoire of requests and their content is very restricted and repetitive. Furthermore, participants in classroom discourse are familiar to each other so very often careful face-work is not necessary in their linguistic output, which translates into a more frequent use of direct requests.

Insightful conclusions can be drawn from research into requests formed by Polish teachers of English conducted by J. Majer and Ł. Salski (2004). Their observations of EFL lessons led them to the conclusion that the majority of teacher requests take the form of: 1) direct orders, 2) performatives, 3) ability questions with can/ could, or 4) obligation statements with must/ have to/ are to... (ibidem: 57-58). J. Majer and Ł. Salski (2004: 60) also underscore a rare appearance in their corpus of suggestory formulas. EFL teachers whose native language is Polish are also prone to use directives because the imperative is a very frequent, socially acceptable means of conveying a request in Polish. In general, they suggest that the requestive output of the EFL teachers whose classes they observed could be described as insignificantly diversified (ibidem: 63-64), and in certain cases showing areas that require improvement.

Finally, our previous research involving NNTs of English in Poland (A. Szczepaniak-Kozak/E. Wąsikiewicz-Firlej, in press) indicated a low variability of their requests rendered in the classroom, which were thematically related mostly to the class context or were used to manage classroom activities. The statistical analysis of the data collected did not confirm any significant correlation between the number and directness of requests and individual differences between the teachers.

Taking the above-discussed research findings into consideration, the general assumption of the present study, whose conduct, design and findings are delivered in the next section, is that we know very little not only about the shape of PC of EFL teachers in Poland, but, first of all, about whether handling of TL pragmatic features during lessons is conditioned by 1) the nativeness/ proficiency of the teacher in the TL pragmatics, and/ or 2) teaching experience. PC is operationalized in our study as rendering requests and, to a lesser extent, their internal mitigation. 


\section{Research design}

As already mentioned in passing, the current research has been to a large extent inspired by the results of our previous study (A. Szczepaniak-Kozak/ E. WąsikiewiczFirlej, in press) on PC of Polish teachers of English. The evident low variability of the requestive forms rendered by the teachers who took part in the study encouraged us to think that perhaps native teachers of English would perform differently in the same educational context. Therefore, we decided to compare and contrast the use of the requestive forms coming from non-native teachers (NNTs) and native teachers (NTs). The data for the study was collected during the observation of four lessons conducted by NNTs and four lessons conducted by NTs. Each of the observed classes lasted 45 minutes. The teachers and students agreed to participate in the study but were not informed about its exact aims in order to avoid the Hawthorne effect.

The requests formulated by the NNTs were extracted from the corpus used in our previous study (ibidem). It was compiled in July 2016 based on the linguistic data acquired from ten class observations, which took place in the period of 01.03.201630.06.2016. We selected two NNTs who declared longer stays in English-speaking countries (over six months) jointly with regular contact with native speakers, and who used the highest number of requestive directness strategies (seven and eight out of nine, respectively) during the observations. The selection took into consideration the fact that teachers who use a considerable variety of strategies provide students with a diversified input, which is a desirable learning setting (G. Kasper 2001b: 36; A. Szczepaniak-Kozak, in press). We also assumed that teachers who have regular opportunities for everyday spontaneous conversations are able to be role-models because they are sufficiently socialized in the TL. The corpus of the requests formulated by two NTs was created in March 2017, based on class observations conducted in February 2017.

As to their educational background, the NNTs are graduates of English studies, holding a PhD (Teacher 1, male) and MA (Teacher 2, female) title. The NTs are both American males who have a BA in English studies as well as a TESOL certificate.

All the classes were conducted by the teachers working for a language school located in Poznań, which specializes in providing educational services to business organizations. The name of the company remains anonymous upon its owners' request. The class participants were exclusively adults - employees of four companies headquartered in the district of Poznań. The classes were conducted in small groups (up to eight people) on the premises of the school's business clients. The participants' level of English was verified with the school's entry tests and interviews and qualified as $\mathrm{B} 2$ in accordance with CEFR, which allows relatively fluent communication and interaction with NSs of English. The language of instruction in the observed classes was, practically and exclusively, English.

The linguistic data collected in the class observation was recorded on an especially designed class observation form, which discerned types of requests in English based on their directness, following the typology developed by S. Blum-Kulka and her colleagues (1989). Additionally, the form contained questions concerning the linguistic means used to mitigate the imposition of the requestive content. From the 
very beginning of our research endeavor, this aspect was treated as optional since we assumed that the use of these means would be scarce and the person observing the classes would find it difficult to take detailed notes embracing a wider range of topics.

\section{Research results}

Based on the data obtained during classroom observations, we created a corpus of 56 requests formulated by the two NNTs and 57 by the two NTs. The requests were classified into nine categories of requestive directness corresponding with the class observation sheet, including: (1) elliptical phrases, (2) imperatives, (3) obligation/necessity statements), (4) need statements, (5) suggestions, (6) predictions, (7) permission questions, (8) ability questions, (9) hints. Table 1 presents the distribution of the recorded requests per individual teacher. A bold line separates direct strategies from indirect ones. The requests were coded numerically (1-9; see the aforementioned specification) for the clarity of presentation.

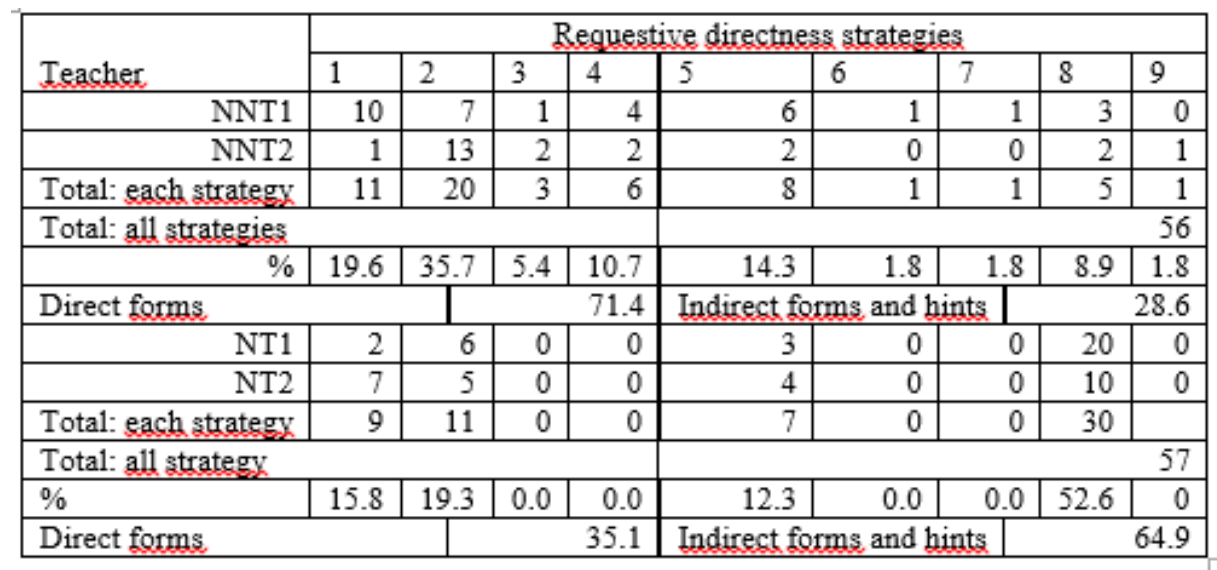

Table 1. Strategies of requestive directness uttered by an individual teacher

As already mentioned, for the current study we chose two Polish teachers whose range of requestive strategies in the corpus analyzed in our previous study was the highest: 7-8 types of requests. Surprisingly, the repertoire of requests rendered by the NTs was narrower not only than that represented by the two NNTs but also by the general average characteristic of the Polish teachers observed by us. In detail, only four categories of requests were found in the native speaker corpus, with an overwhelming domination of ability questions (almost 53\%), while in our previous study (A. Szczepaniak-Kozak/ E. Wąsikiewicz-Firlej, in press) the majority of NNTs used 5-6 types of requests. The data presented in Table 1 also confirms the tenet that requests rendered by Polish teachers of EFL are predominantly direct in form (cf. J. Majer/ Ł. Salski 2004). Over 70\% of the NNTs' requests were categorized as direct and the remaining $30 \%$ as indirect, compared to the reverse trend in the NT corpus: $35 \%$ direct requests versus $65 \%$ indirect requests.

As far as the NNTs' predilection for direct strategies is concerned, it might be argued that the dominance of such pragmalinguistic forms is not a characteristic 
feature of classroom discourse but rather it is a result of the negative sociopragmatic transfer from Polish (their MT). In Polish culture, which is characterized by a large power distance, a person higher in (organizational) hierarchy (here the NNT) is typically more direct. Additionally, the sociocultural transfer was enhanced also by the imperative mood characteristic of the instructional materials used. Finally, monoclausal imperatives were the most frequently recorded requestive strategy in the NNT corpus (36\%), irrespective of the level of instruction. Extract 1 illustrates the most typical application of this strategy in the NNT corpus.

\section{Extract 1: Imperatives \\ Take a look at... \\ Choose a room and describe it. \\ Don't show it to anybody.}

One might expect that in higher proficiency levels (e.g., B2) the structural complexity of the teacher language would increase; however, that was not the case in our observations. There was only one example of a biclausal prediction in our corpus: I was wondering if you would give me the synonym for that. At the same time, every fifth request in the NNT corpus took the form of elliptical phrases, which were ranked the second most frequent strategy (see Extract 2).

\section{Extract 2: Elliptical phrases \\ Any other? \\ Number 3. \\ The next one.}

To sum up, the two most frequent strategies in the NNT data are indeed laconic and impersonal. Furthermore, the NNTs fail to use any forms of address while requesting their students, which creates a sense of distance between the teacher and the students and enhances the teacher's domination in class. By contrast, the NTs tend to address students by their first names that typically precede even the simplest requests, e.g.: Karol, your turn (NT1).

Suggestions were ranked the third most frequent strategy (14.3\%) in the NNT corpus. Notably, this category was overwhelmingly dominated $(87.5 \%)$ by the structure let's + infinitive (see Extract 3 below).

Extract 3: Suggestions

Let's see what you've got.

Let's give it a try.

Altogether, the share of the top three strategies is almost $70 \%$ of the whole NNT corpus that translates into a rather poor diversity of the input which the teachers provided in class. The remaining strategies comprised need statements $(10.7 \%)$, ability questions $(8.9 \%)$, obligation/necessity statements $(5.4 \%)$, exemplified by Extract 4, 5 and 6, respectively. The remaining three strategies, i.e., predictions, permission questions and hints, were used only once by the teachers.

Extract 4: Need statements

I want you to tell me what it is. 
Extract 5: Ability questions

Can you read the sentence, please?

Extract 6: Obligation/necessity statements

Your job will be to...

It must be underscored here that can + infinitive is the exclusive pragmalinguistic form used by both NNTs (100\%) to render ability questions (Strategy 8). That can be used as an argument that experienced NNTs can provide students with input which is very demanded in EFL learning settings. According to A. Szczepaniak-Kozak's (in press) study, within two corpora of NS spoken macro/register ${ }^{3}$, the frequency figure for can you $(19,392$ in total) is much higher than the figure for could you $(4,404)$. It means that the rendering of the lion's share of requests in NS English involves the use of the modal verb can rather than could (A. Szczepaniak-Kozak, in press). At the same time, could you is the construction which Polish speakers of EFL prefer (ibidem).

Turning now to the diversity of the requestive strategies applied by the NTs, it is relatively lower than that represented by the NNTs - the NTs used only four types of requests. Along with the narrow range of the requestive types, the NT corpus is dominated by ability questions (52.6\%). However, pragmalinguistic devices used to form this strategy are more varied: could you + infinitive, would you + infinitive, can you + infinitive (see Extract 7). In fact, the structure could you + infinitive prevailed in this category (53\%), which might come as a surprise when juxtaposed with the statistics generated from the NS corpora referred to above. Relatedly, our results are not representative as we analyze only two case studies, which might provide insight into teachers' idiosyncrasies and not necessarily reflect major trends.

Extract 7: Ability questions

Could you think of another word?

Would you continue, please Karol?

Can we meet on Monday?

Even though the use of imperatives was less frequent in comparison to the NNTs, this strategy was identified in almost one-fifth of the requests in the corpus (see Extract 8). Another discernible feature within this category appears to be a more frequent use of internal mitigation by the NTs (e.g., please, $O K$ ).

Extract 8: Imperatives
Continue, please.
Explain.
Hold on.

Nearly $16 \%$ of the requests formulated by the NTs were elliptical phrases. In contrast to the NNTs, the NTs preceded such phrases with students' first names serving the function of alerters (see Extract 9).

${ }^{3}$ Corpus of Contemporary American English and Birmingham Young University - British National Corpus; 
Extract 9: Elliptical phrases

Marek, your turn.

Ola, page 4, please.

Finally, suggestions were ranked the least frequent requestive strategy identified in the NT corpus (see Extract 10). Similarly to the NNTs, this strategy was mainly realized by the structure let's + infinitive (71\%). Again, this finding actually clashes with the frequency trends in the NS English corpora (A. Szczepaniak-Kozak, in press) in which the how about/ what about structures dominate.

Extract 10: Suggestions

Let's stop for a while.

How about going to Posnania?

What about Wednesday?

The eight observed classes significantly differed in terms of classroom management techniques and their verbal realizations as well as the methodological expertise of the teachers, which in our view might explicate the impoverished pragmatic input provided by the NTs. The both Polish NNTs, fully qualified and experienced language instructors, used a variety of teaching materials (text, video, audio), informed the students about the aims of the classes, monitored their work and provided feedback. Their classes were divided into discernible phases with their own objectives tuned with the major lesson aims. Such an organization ensured the dynamism of instructional communication, boosted student engagement and helped to avoid boredom and monotony. Moreover, their students were encouraged to work in pairs and small groups, which enhanced cooperation and real interaction, possibly offering more opportunities for formulating requests. The classes conducted by the NTs, on the other hand, were less efficiently organized and mostly involved text reading followed by discussion. The NTs majored in classic philological studies without a specialization in teaching. Their pedagogical preparation is limited to the TESOL course (around 120-140 hours). Furthermore, we posit that their choice of the lesson format (reading and discussion) might have significantly influenced the use of requests because the very class context limited their thematic scope, not only in the teacher's but also in the students' output. Accordingly, in most cases the NTs asked their students to continue or stop reading, take turns or express their opinions about the issues discussed in the analyzed texts. The students were noticeably bored, so the general level of interaction in the classroom was low. On the top of that, despite the students' fluency and eagerness to talk, the NTs dominated the classroom discourse and were self- rather than student-focused, that is, the teachers continued to share their experiences and comments instead of eliciting responses from the students. The interaction in class was limited to student-teacher interaction; the NTs did not really encourage any form of communication between the students. Very occasionally, the students took initiative and asked their peers to share their opinions, which might be interpreted as an overt expression of their need for interaction and breaking the class routine. This observation would support L. Wyner and A. Cohen's (2016: 542) suggestion that "it is then imperative that FL teachers also incorporate pragmatics in 
their instruction, particularly if student motivation is lacking to pay attention to the subtleties associated with this construct".

The abovementioned observations might imply that the classroom settings put limitations on the language used by the teacher, which is a factor often neglected. For instance, the requests rendered by teachers oscillate mainly around topics related to classroom/time management. Our class observations allow us to conclude that certain interactional exchanges constantly reappear and some others never do, which naturally has a colossal influence on what type of pragmatic features the students are exposed to. In such settings, they hardly ever hear requests typical of everyday discourse, e.g., requests for favors between familiar to each other people or for services in professional situations. Additionally, teachers' skills and their methodological preparation play a considerable, if not decisive role, in creating a more linguistically, including pragmatics, diversified classroom environment. In other words, being a native speaker does not automatically translate into providing a richer input and more effective teaching. Nonetheless, neither the NNTs nor the NTs are aware of pragmatic aspects of discourse and the both groups require teacher trainings concerning the importance of PC in everyday discourse jointly with tasks which foster its development in the classroom.

All in all, although we realize that our study is a preliminary effort at understanding the pragmatics of teacher discourse, we would like to underscore that authentic lessons of EFL do not show a full range of pragmatic features either in input or in output. Very often the classroom discourse is dominated by the teacher who prefers a very restricted scope of, for example, speech acts. In a sense, our data shows that indeed "the pedagogical message works in direct opposition to the interactional message" (P. Seedhouse 2001: 349) because conversation is not a typical discourse format that appears in the classroom. By definition, in conversation "turn-taking and participation rights in conversation must be unrestricted; responsibility for managing and monitoring the progress of the discourse must be shared by all participants; conversations are open-ended, and participants jointly negotiate the topic" (P. Seedhouse 1996: 18). Therefore, at least in theory, it is not possible for teachers to converse in the classroom as a part of a lesson nor is it possible for learners to genuinely converse in the classroom because such discourse will always be in some way connected to the pedagogical purpose which the teacher introduces (P. Seedhouse 1996: 21-22), except, perhaps, for learner chatter when it escapes the teacher's attention. However, a skilful instructor may provide learners with substitute settings for conversation by means of context-appropriate modeling. This goal should be promoted in teacher training and textbooks.

\section{Concluding remarks and future perspectives}

Our research findings enable us to agree with A. Cohen (2016: 566) that "in an FL instructional context, the teaching of TL pragmatics is a challenge for both an NT and an NNT". This is so because classroom discourse is an institutional variety of discourse, in which interactional elements correspond neatly to institutional goals. At the same time, the absence of PC training in philological education bears disastrous 
consequences not only on the shape of teacher-trainees' own PC but also on the PC delivered to their (prospective) students in the classroom. Our research indicates that whether the language instructor is a native speaker or not appears to be of lesser importance for an effective development of PC in the classroom. What truly matters is a demonstrable linguistic and pragmatic competence, along with appropriate professional training. We propose that some degree of proficiency in pragmatics and its teaching should be a requirement for a certificate or diploma for any future FL teacher (cf. also L. Wyner /A. Cohen 2016: 542).

It goes without saying that the routine and limited repertoire of teacher talk causes impoverished language input in the classroom in general, which consequently does not stimulate learner achievement in this area. Shortages of teachers' own PC make it impossible for them to think critically and objectively about their own performance in the classroom, and consequently to modify their teaching. Additionally, the development of PC is considerably hindered by the nature of the classroom discourse. Therefore, we are in total agreement with P. Seedhouse (1996: 22) that: "communicative theorists would like to see teachers introducing the pedagogical purpose of replicating genuine discourse or conversation. But as soon as the teacher has introduced any pedagogical purpose at all, even if the instruction is to 'have a conversation in English', he or she has ensured that what will occur will be institutional discourse rather than conversation".

There are various means which teachers can exploit in order to tackle shortages of classroom discourse. First of all, teachers can enhance their students' pragmatic development by fostering interactional authenticity (L. Bachman 1990), that is, to "require them to use language in ways that closely resemble how language is used naturally outside the classroom" (R. Ellis 2005: 5-6), and thus exploit slots for real interactions in the classroom. Student-centered classroom organization formats, e.g., role plays, group problem-solving tasks, can also stimulate an increase in students' range of speech acts and politeness strategies. Additionally, it is highly recommendable to include authentic and contemporary materials. Teachers are not left to themselves in this matter as the number of studies proposing techniques and activities which secure authenticity in teaching, is on increase. Since foreign language learners lack frequent opportunities to participate in interactions in the TL, audiovisual materials (films, cf. A. Martínez-Flor 2007) or online interactions (etandems, cf. R. Shively 2010) can serve as sources of not only appropriate and varied language material but can also foster student noticing that leads to pragmatic awareness. Both of these conditions may offset the disadvantage of learning outside the second language context (cf. A. Cohen 2016: 566).

\section{References}

Akikawa, K. (2010), Teaching pragmatics as a native speaker and as a non-native speaker. In: B. Brady (ed.), WATESOL NNEST Caucus Annual Review Vol. 1, 43-69. (URL https:// www.academia.edu/816235/Students_appraisal_of_their_ native_and_non-native_English-speaking_teachers). [Accessed 1.10.2017]. 
Bachman, L. (1990), Fundamental considerations in language testing. Oxford.

Bardovi-Harlig, K. (2001), Evaluating empirical evidence: Grounds for instruction in pragmatics? In: K.R. Rose/ G. Kasper (eds), Pragmatics in language teaching. Cambridge, 13-32.

Bardovi-Harlig, K./ B. Hartford (1993), Learning the rules of academic talk: A longitudinal study of pragmatic development. In: "Studies in Second Language Acquisition" 15(3), 279-304.

Blum-Kulka, S./ J. House/ G. Kasper (eds) (1989), Cross-cultural pragmatics: Requests and apologies. Norwood, NJ.

Cenoz, J. (2008), The acquisition of pragmatic competence and multilingualism in foreign language contexts. In: E. Alcón Soler/ M. Safont-Jordà (eds), Intercultural language use and language learning. Berlin, 123-140.

Cohen, A. (2016), The teaching of pragmatics by native and nonnative language teachers: What they know and what they report doing. In: "Studies in Second Language Learning and Teaching" 6(4), 561-585.

Droździał-Szelest, K. (2011), Oral skills awareness of advanced EFL learners. In: M. Pawlak/ E. Waniek-Klimczak/ J. Majer (eds), Speaking and instructed foreign language acquisition. Bristol, 131-148.

Ellis, R. (1992), Learning to communicate in the classroom: A study of two language learners. In: "Studies in Second Language Acquisition" 14(1), 1-23.

Ellis, R. (2005), Instructed second language acquisition: A literature review. Auckland.

Eslami-Rasekh, Z. (2005), Enhancing the pragmatic competence of NNEST candidates. In: "NNEST Newsletter" 7(1), 4-7.

Eslami, Z./ A. Eslami-Rasekh (2008), Enhancing the pragmatic competence of nonnative English-speaking teacher candidates (NNESTCS). In: E. Alcón Soler/ A. Martínez-Flor (eds.), Investigating pragmatics in foreign language learning, teaching, and testing. Bristol, 178-197.

Félix-Brasdefer, J. (2008a), Pedagogical intervention and the development of pragmatic competence in learning Spanish as a foreign language. In: "Issues in Applied Linguistics" 16(1), 47-82.

Félix-Brasdefer, J. (2008b), Teaching Spanish pragmatics in the classroom: Explicit instruction of mitigation. In: "Hispania" 91(2), 477-492.

Gomez-Laich, M. (2016), Second language learners' divergence from target language pragmatic norms. In: "Studies in Second Language Learning and Teaching" 6(2), 249-269.

Ishihara, N. (2011), Co-Constructing pragmatic awareness: Instructional pragmatics in EFL teacher development in Japan. In: "TESL-EJ" 15(2). (URL http://www.tesl-ej.org/wordpress/issues/volume15/ej58/ej58a2/). [Accessed 1.10.2017].

Kachru, B. (1985), Standards, codification and sociolinguistic realism: The English language in the outer circle. In: R. Quirk/ H. Widdowson (eds), English in the world: Teaching and learning the language and literatures. Cambridge, 11-30. 
Kasper, G. (2001a), Four perspectives on L2 pragmatic development. In: "Lingwistyka Stosowana/ Applied Linguistics/ Angewandte Linguistik" 22(4), 502-530.

Kasper, G. (2001b), Classroom research on interlanguage pragmatics. In: K. Rose/ G. Kasper (eds), Pragmatics in language teaching. Cambridge, 33-60.

Kasper, G./ K. Rose (2002), Pragmatic development in a second language. Oxford.

Klimczak, A. (2011), British politeness in a Polish ESL/EFL classroom? In: M. Pawlak (ed.), Extending the boundaries of research on Second Language Learning and Teaching. New York, 93-102.

Krawczyk-Neifar, E. (2004), The role of proficiency factor in the development of pragmatic awareness among Polish learners of English. In: J. Arabski (ed.), Pragmatics and language learning. Kraków, 37-49.

Majer, J./ Ł. Salski (2004), The pragmatics of classroom discourse: Requests and commands. In: J. Arabski (ed.), Pragmatics and language learning. Kraków, 5167.

Martínez-Flor, A. (2007). Analysing request modification devices in films: Implications for pragmatic learning in instructed foreign language context. In: E. Alcón Soler/ M. Safont-Jordà (eds), Intercultural language use and language learning. Dordrecht, 245-280.

Martínez-Flor, A./ E. Usó-Juan (2010), The teaching of speech acts in second and foreign language instructional contexts. In: A. Trosborg (ed.), Pragmatics across languages and cultures Vol. 7. Berlin, 423-442.

Niezgoda, K./ C. Rövern (2001), Pragmatic and grammatical awareness: A function of learning environment? In: K.R. Rose/ G. Kasper (eds), Pragmatics in language teaching. Cambridge, 63-79.

Pawlak, M. (2006), The place of form-focused instruction in the foreign language classroom. Kalisz/ Poznan.

Savič, M. (2016), Do EFL Teachers in Serbia have what they need to teach L2 pragmatics? Novice teachers' views of politeness. In: K. Bardovi-Harlig/ C.J. Félix-Brasdefer (eds), Pragmatics \& Language Learning Vol. 14. Honolulu, $207-$ 231.

Schauer, G. (2009), Interlanguage pragmatics development: The study abroad context. London.

Seedhouse, P. (2001), The case of the missing "no"; The relationship between pedagogy and interaction. In: "Language Learning" 51, Supplement 1, 347-385.

Shively, R. (2010), From the virtual world to the real world: A model of pragmatics instruction for study abroad. In: "Foreign Language Annals" 43(1), 105-137.

Szczepaniak-Kozak, A. (2010), Interkulturowa kompetencja komunikacyjna $z$ perspektywy nauczyciela języka angielskiego. In: M. Mackiewicz (ed.), Kompetencja interkulturowa w teorii i praktyce edukacyjnej. Poznań, 125-136.

Szczepaniak-Kozak, A. (2016), Developmental trends in requests rendered by EFL speakers in Poland. In: "Konińskie Studia Językowe" 4(4), 491-512. (URL http://ksj.pwsz.konin.edu.pl). [Accessed 1.10.2017]. 
Szczepaniak-Kozak, A. (in press), Interlanguage pragmatic competence: A longitudinal study of 'pragmatic accent' in learning EFL. Poznań.

Szczepaniak-Kozak, A./ E. Wąsikiewicz-Firlej (in press), Rola różnic indywidualnych w nabywaniu kompetencji pragmatycznej przez nauczycieli języka angielskiego. In: "Neofilolog".

Taguchi, N. (2011), Pragmatic development as a dynamic, complex process: General patterns and case histories. In: "Modern Language Journal" 95(4), 605-627.

Taguchi, N. (2015), Instructed pragmatics at a glance: Where instructional studies were, are, and should be going. In: "Language Teaching" 48(1), 1-50.

Vásquez, C./ A. Fioramonte (2011), Integrating pragmatics into the MA-TESL program: Perspectives from former students. In: TESL-EJ 15(2), 1-22.

Wyner, L./ A. Cohen (2015), Second language pragmatic ability: Individual differences according to environment. In: Studies in Second Language Learning and Teaching 5(4), 519-556.

Yates, L./ G. Wigglesworth (2005), Researching the effectiveness of professional development in pragmatics. In: N. Bartels (ed.), Applied linguistics and language teacher education. New York, 261-280. 